\title{
The Indo-Sri Lankan Accord in Perspective
}

\author{
By Lakshman M. Marasinghe*
}

\section{Historical Benchmarks}

\section{(a) The early history}

Historians have traced the historical antecedents of the ethnic conflict in Sri Lanka to the beginning of the 20th Century. They cite the governorships of Sir Robert Chalmers (1918-25) and his successor Sir Hugh Clifford (1925-27) and the two divisive constitutions that straddled their periods of governance of the then Colony of Ceylon as sowing the seeds of ethnic discord. Those seeds fell upon terrain made acutely fertile by the ethnic discord experienced by the only truly multi-ethnic organisation, the Ceylon National Congress during the 1920s. The break-up of the Ceylon National Congress and the establishment of the Sinhala Maha Sabha by a former Prime Minister of Independent Ceylon, Soloman Bandaranaike, in 1934, confirmed the separation of the two ethnic groups - the Sinhalese and the Tamils - into two distinct camps. The founding of Bandaranaike's Sinhala Maha Sabha (The Great Congress of the Sinhalese) was matched a few years later by the establishment of the Tamil Congress by G.G. Ponnambalam. The plea made (in 1947) by Ponnambalam before the Soulbury Commission, which was enquiring into the grant of independence to Ceylon, was that Sinhalese and Tamils, despite their enormous disparity in numbers, be awarded parity of status - the 50:50 plea, as it was then called. The Soulbury Commissioners recommended, and the British government accepted their recommendation, that minority rights be given protection under an entrenched clause in an Independent Constitution. Ponnambalam who asked for parity of status appears to have accepted that position, for in 1948 his party joined the predominantly Buddhist, Sinhala administration of D.S. Senanayake as a coalition partner, to form the first independent administration on the island. Ponnambalam himself accepted the important portfolio of Industries, Industrial Research and Fisheriesı.

The uniqueness of the grant of independence to Ceylon in 1948 was highlighted by the fact that, Britain, unlike what it did in many other colonies, did not insist on laying down a nationality provision in the first constitution. Britain allowed an independent Ceylon to decide on that issue, and in 1949 the newly Independent Dominion of Ceylon enacted the

* ("The author was commissioned by The Marga Institute in Colombo, Sri Lanka, to organise a séries of meetings involving foreign experts to examine the varying dimensions of the many proposals that spaned the period between 1983 and 1986. In addition, the author did a certain amount of fact finding in 1985, enquiring into the Tamil-Muslim riots in the Eastern Province. These and other activities during the 1983-86 period which helped him to collect a mass of documentary materials provided the basis for this paper.") 
Indo-Pakistani Citizenship Act which particularised those of Indian and Pakistani nationalities and placed specific restrictions upon their becoming citizens of an Independent Ceylon. Ponnambalam's Tamil Congress managed to win a majority in their own party caucus to support that bill. Ponnambalam voted in favour of that bill, compelling a large minority of his supporters to break away to form the Ilanka Tamil Arasu Kachchi (Lanka Tamil State Party) which came to be known as the Federal Party. This was led by one of Ponnambalam's trusted lieutenants and a fellow Chelvanayakam KC, between 1949 and 1977, the Federal Party forged ahead as the leading political party of the Tamils. The power of Ponnambalam's Tamil Congress came to rest solely on the personal popularity and the historical connections of the party and its leader to the city of Jaffna. As long as Ponnambalam was alive, he remained the only representative in Parliament for his party occupying the parliamentary seat for Jaffna. The rest of the 15-16 seats were all occupied by the breakaway Federal Party. During some historical periods the Tamil Congress may have won another parliamentary seat, particularly that of Nallur and/or Kalkuda, but to a large extent Ponnambalam remained the only representative in Parliament for the Tamil Congress. In the meantime the SLFP government in 1958 passed the Official Language Act declaring Sinhala the sole of ficial language of the island.

The polarisation between the Sinhala and Tamil races began to reach a crescendo by 1976 and, on May 14th of that year, the Federal Party, at its annual Congress held in Vaddukodai passed a resolution which provided the beginnings of the Tamil march towards separation. By the Vaddukodai Resolution the Federal Party resolved to call itself 'The Tamil United Liberation Front' and from that moment to ask for Eelam, or a Separate Tamil State. In the meantime, in 1977 general elections were called, the United National Party, headed by J. R. Jayewardene, secured more than a two-thirds majority in Parliament reducing Mrs. Bandaranaike's SLFP to 9 seats. The TULF having won all Tamil seats - then 18 in number - its leader Amirthalingam, was awarded the status of Leader of the Opposition. Between 1977 and 1983 a number of killings of government and quasi-government officers had taken place, both in the North and in the East, signalling the commencement of a well-articulated guerilla movement. During this time, the Tamil guerillas escalated the war by introducing many sophisticated weapons such as rocket-propelled grenades and landmines into the conflict. On July 23, 1983, the guerrillas ambushed a convoy of the Sri Lankan Army, killing 13 Sinhala soldiers. This sparked off a spell of anti-Tamil riots, both in Colombo and in other parts of the island, resulting in the damage and destruction of Tamil property and in the death of nearly 500 Tamils. As a response to this, and on August 5th the same year, Parliament enacted what has now come to be known as the 'Sixth Amendment' to the Constitution. Under that amendment all members of Parliament were called upon to reaffirm their allegiance to a unitary state. This made the position of the T.U.L.F. members of Parliament untenable: the T.U.L.F. had by then become a separatist party and the contents and the requirements of the 'Sixth Amendment' were clearly unacceptable to them. The 16 
members of the T.U.L.F. (two having defected to the governing U.N.P. in 1978 and third in 1979), therefore refused to take their oaths of allegiance under the Sixth Amendment', which resulted in their ceasing to be members of Parliament. With the absence of the 16 T.U.L.F. members, the S.L.F.P. under Mrs. Bandaranaika's son, Anura, took over the leadership of the opposition.

Up to this point, it must be emphasised that India did not participate in any process of conciliation. India surreptitiously provided the varying guerilla groups a safe haven, training facilities and bases for logistrical operations across the Palk Straits. But it is clear that India played a role (albeit passively) in the conflict by allowing its territory in Tamil Nadu to be used as a training ground for the budding terrorist groups. India felt pressure from Tamil Nadu at this point to step into the conflict. She did in August 1983, by dispatching her Foreign Minister, Narasimha Rao and the then Indian Prime Minister Indira Gandhi's Foreign Policy Advisor, Gopalaswamy Parathasarthy, who was himself al Tamil, to Colombo. The mission was only to act as a go-between and help the government of Sri Lanka and the Tamil separatist groups to meet, talk and forge new proposals for a settlement. It must be understood that, from August 1983 until the middle of July 1987, India never proposed a settlement between herself and the government of Sri Lanka. In every step, India was principally playing the part of an 'honest broker' and never suggested that a decision between the two governments should in any way transcend the aims and aspirations of the Tamil people in Ceylon or the separatist groups that claimed to represent them. The change in this posture came in July of 1987. Despite this fact, the importance of the Indian role in any settlement became increasingly clear, as India continued to play host to the separatists.

\section{The Proposals for a Settlement: Annex' C'}

As a result of sustained shuttle diplomacy undertaken by Parathasarthy from August to November, 1983, a proposal that would secure the agreement of the Indian Government and which therefore could be forced down the throats of the reluctant separatists, was hammered out and was set out as an annexé to a Sri Lanka government communiqué addressed to all the political parties on the island. This was 'Annex Cr. Under those proposals, administrative units which were larger than the old District Development Councils and certainly smaller than the present Provinces were proposed. These were to be called 'Regional Councils` with internal powers of administration in such areas as law and order, justice (including a court system), an internal economic development programme and a specific land policy, responsibility for the provision of education, health, welfare and social services. There were shared areas proposed for taxation, transport and communications. What was absolutely not even considered was any linkage among several Regional Councils. These proposals arose out of the extensive talks that Parathasarthy conducted with the Sri Lanka Government.

President Jayewardene called the All Party Conference (A.P.C.) to consider these pro- 
posals on January 10, 1984. While claiming to be non-political but being acutely concerned with the well-being of the Sinhala Buddhists, the Buddhist clergy claimed and won a seat at the A.P.C. While inviting the Buddhists, the President invited all other religious bodies: the Hindus, the varying denominations of the Christians, and also the Muslims. The A.P.C. eventually became something like a university debating society, meeting each day for a few hours after 4:30 p.m. at the Bandaranaike Memoiral International Conference Hall (B.M.I.C.H.). The futility of this exercise became apparent by September 1984 for the participants remained rooted to two basic propositions: those who proposed District Development Councils (D.D.C.) and no more and those who asked for Regional Councils and no less. On September 30, 1984, the A.P.C. ended its last session - officially, it was declared to have been postponed sine dier.

The opposition to the proposals contained in Annex $/ C$, was well articulated and most vociferous. The proposals themselves when compared with the present accord between President Jayewardene and Prime Minister Gandhi of July 29th, 1987 seemed tame, but the overwhelming opposition mounted by the Sinhala-Buddhist lobby frightened the government into abandoning them. Needless to say that India, then under Mrs. Indira Gandhi, was not coming in as a guarantor of peace but was principally blessing the proposals.

\section{The Draft Bill of December 1984}

Undaunted by the débâcle at the hands of the A.P.C., Jayewardene attempted to some areas of agreement and some areas where there was no disagreement at the A.P.C. together and plaster over any cracks with some ideas that he thought he could get the Indian Government and the T.U.L.F. to accept; through their joint efforts he made a pitch to the separatists to come to a settlement. With this framework in mind Jayewardene proposed the Tenth Amendment to the Constitution which contained the draft District and Regional Councils Bill in December 1984. The ideas contained in this 1984 draft Bill appear to have influenced the contents of the 1987 accord in at least on aspect. The bill of 1984, proposed the creation of Regional Councils only where the District Development Councils contained within the boundaries of the proposed Regional Councils did consent to merging with other D.D.C.s to form the Regional Council. It was thought that this would allow the D.D.C.s in the Tamil areas to join together and by the joining expand into one gigantic Regional Council. The amalgamation of D.D.C.'s to form a larger unit was conditioned by the socio-economic needs of the area in question. The resultant unit may comprise many D.D.C.'s. But the number of D.D.C.'s that would join to form each regional council was never a pre-determined figure. Therefore each resulting Regional Council would equally vary in size depending on the factors of socio-economic dimensions which might make the joining of D.D.C.'s necessary. It may however be mentioned that the whole idea of D.D.C.'s raised unhappy memories for the Tamils. When D.D.C. elections were held in 1980 the election itself was characterised, 
particularly in the North, as a fraud and six ballot boxes were totally lost while under government control. The resulting D.D.C.'s never got off the ground because the government did not provide the necessary financial support to make the Council a reality. D.D.C.'s therefore died in the North as soon as they were born, and that left a bad taste in the mouths of the Tamils. This is true in the East of the island as well. In contrast D.D.C.'s took root in the rest of the island and they do exist even to this day making a very limited contribution to development and a large contribution to the complexities of bureaucratic administration of the South.

Be that as it may, the government's proposals of D.D.C.'s as a starting point responded to the wishes of the Buddhist clergy and the majority of the Sinhalese. The ability of the D.D.C.'s to join together to form larger units - the Regional Councils - corresponded to the demands of the Tamils and Parathasarthy. The idea of linkage was also thought to satisfy the Muslim population in the East, by giving them an opportunity to form their own Regional Council. This too was to be achieved by the collective will of adjacent D.D.C.'s to join in the venture of forming Regional Councils. The July 1987 Accord in contrast gave the people in the North and the East a single area, composed of the Northern and Eastern Provinces instead - with a right to separate to their former positions, if they so wished, after a referendum. The 1984 draft bill gave smaller units a right to merge by consent. There is a world of a difference between what the 1987 Accord gave the Tamils and what the 1984 bill proposed for a settlement. The draft bill additionally provided certain policing, taxing and administrative powers. The draft bill also envisaged a second chamber for the whole island which would have 75 members comprising 25 chairpersons and 25 vice-chairpersons of the 25 D.D.C.'s on the island, plus another 25 appointed by the President himself. These proposals were acceptable to the T.U.L.F., although some further discussions were necessary. At this point the T.U.L.F. was beginning to feel that their constituencies were being dominated by the guerrillas, and therefore wished dearly to re-capture and re-establish their lost image. On the other hand Jayewardene seemed largely irritated by the obstacles placed at the A.P.C. meetings by a small group of laymen headed by the well-known lawyer, Gamini Irriyagolle and the clergy led by Ven. Madihe Pannasiha. In addition, Jayewardene's own Cabinet Minister and party stalwart, Cyril Mathew unleashed his own bombshell an assessment of the Tenth Amendment in his 'Letter to Sinhala Friends. His assessment was of the contents of the draft bill which in fact constituted the Trenth Amendment to the Constitution. This precipitated inter alia Mathew's dismissal from the cabinet on December 24th, 1985.

It must be mentioned that the draft bill of 1984 had more than an even chance of providing the foundation for a settlement. But an unfortunate mistake made it yet another wasted opportunity. Jayawardene, intending perhaps to make a direct contact with the T.U.L.F. and other Tamil bodies, declared on 21 st December, 1984 that the A.P.C., as a forum for examining proposals for a settlement, was dissolved. It may be safely said that Jayewardene's experience with the A.P.C. had not been a pleasant or 
fruitful one. He found the A.P.C. a hindrance to a settlement bent on opposing every reasonably viable proposal that came before it. He had perhaps thought that the lowest common denominators that he had collected in the draft bill were best put to his adversaries in the Tamil Camp directly and without intermediaries. The unfortunate occurrence was that Amirthalingam, the leader of the T.U.L.F. upon hearing Jayawardene's declaration that the A.P.C. was terminated assumed that the President had reached the end of his line and had been forced to give in to Sinhala pressures. Amirthalingam, who had remained in Colombo until that announcement, left almost immediately for Madras stating to the press that the talks were over and that in his view the Sri Lanka Government has chosen a military solution for the problem. This may be the reason that, in early 1985, fighting in both the Northern and Eastern Provinces intensified and the regions came under the firm grip of the guerrilla forces. The government's reaction to this was the creation of a new élite para-military police force - the Special Task Force, STF.

The Tenth Amendment was nonetheless passed and the government used the amendment to prepare the people to accept the idea of a federal solution for the problem. But the solution was far from becoming a reality. During the first six months of 1985 hostilities in both provinces reached a new pitch.

\section{To Thimpu and Back}

President Jayewardene's announcement that the A.P.C. had ended and the concommitant flight of Amirthalingam to Madras opened a new period of despondency. The government of Sri Lanka looked around to blame someone for this unfortunate and unexpected turn of events. Jayawardene accordingly asked for a change of personnel. India was by now under the premiership of Rajeev Gandhi (Indira Gandhi having been assassinated). He very promptly responded by taking Gopalaswamy Parathasarthy, a Hindu, a Tamil and one with interests in the publishing house that brought out the pro-Tamil Hindu daily, 'The Hindu, away from the negotiating scene. Parathasarthy was duly replaced by an affable anglicized gentleman, Romesh Bhandari. At the same time both Sri Lanka's Minister for National Security, Lalith Athulathmudali and another Esmond Wickramasinghe (a king maker in Sri Lanka's ruling United National Party and a confidant of President Jayawardene), made a much publicised visit to New Delhi. Both were received with warmth and cordiality by Rajeev Gandhi. The visit was to see whether a new round of talks could commence and to test India's mood after the collapse of the A.P.C. This visit paved the way for a mini summit between Jayawardene and Gandhi in June 1985 - first in New Delhi and later in Dacca. This meeting for the first time since 1983 produced results. Most importantly, Gandhi declared his adherence to the idea of a unitary state in Sri Lanka and persuaded the Tamil guerrillas to observe a ceasefire as from June 18,1985 . The ceasefire, however, only lasted several weeks. Gandhi also invited Jayawardene to send to India a delegation of Sri Lankan lawyers to 
engage in a dialogue with Gandhi's own Attorney-General so that some important bench-marks for a future dialogue with the Tamil Separatists might be fixed. Jayawardene did this in June by sending a group of Constitutional experts including his own brother, Dr. H. W. Jayewardene, as the head of the delegation.

The talks with the Indian Attorney-General proved valuable and both India and Sri Lanka, thought it advantageous to have another round of talks with the Tamil Separatists. As Khatmandu was in the throes of civil unrest, the tranquil of Thimpu, in the Kingdom of Bhutan, was selected as the venue. Two sets of meetings were held, the first in July 8-13 and the follow-up meetings in August 12-17, 1985.

The Thimpu meetings produced nothing of substance towards a settlement. But two matters become crystal clear. First, they set the tone for future dialogues with India, when she would play a more effective role than merely that of a honest broker. At Thimpu, India took centre stage and Bandhari, with all his skills and tact succeeded in wrenching a communique from the six Tamil groups which stated that they favoured a negotiated settlement. At Thimpu Bandhari tacitly made it clear that the separatist groups were in truth guests of the Indian Government, having established their military bases and training camps in the southern Indian state of Tamil Nadu. If India were to move against these separatists groups by evicting them from Indian soil, then the obvious result, it was made clear, would be to hamper and even seriously frustrate their fight for a separate state in Sri Lanka. Bandhari made this known to the separatists groups at Thimpu. In addition Bandhari made the participants at Thimpu aware that India might use that power at the opportune moment to settle the conflict. To make India's strength abundantly clear to the separatists, Gandhi had Balasingham and Chandrahasan, two of the Tamil separatists who refused to go to Thimpu, arrested, put under house arrest and later deported from the country. Balasingham at the time was the chief of the political bureau of the Liberation Tigers of Tamil Eelam (L.T.T.E.) in Madras and Chandrahasan was the Head of the Organisation for the sprotection of Tamils of Eelam from Genocider (P.R.O.T.E.G.) also of Madras. Balasingham who was found to be a citizen of the United Kingdom was deported to the U.K. and Chandrahasan who still was a Sri Lankan citizen holding a valid visa for the United States of America, was flown to New York aboard an Air India flight. Upon arrival at John F. Kennedy airport, Chandrahasan refused to alight from the aircraft thus compelling the airline to take him back to Bombay. At Bombay Chandrahasan was detained by the Indian authorities. Both Chandrahasan and Balasingham were later re-admitted but this was after having them eat as much humble pie as the Indians chose to feed them. India's strength, power and strategic importance are factors which Sri Lanka should have recognised not in 1987, July 29th, after many more hundreds had died but as early as July 1985. The futility of attempting a solution without India's help was abundantly clear even as early as in 1985 , if not earlier.

The second factor flowing from the Thimpu meetings was that India managed to force out of the Tamil separatists a statement outlining their minimum objectives. These, four 
principles, were laid down in a joint statement by the separatists on 13th July, 1985. These four principles were: First, that Tamils be recognised as a distinct nationality. Second, that Tamils be associated with a distinct homeland. This was done after two years and many hundreds of deaths later in the 1987 accord. Third, that Tamils be provided with a right to self-determination. Fourth, that all Tamils should have the right to full citizenship in Sri Lanka. This was subsequently recognised and reiterated in the 1987 Accord. The Sri Lanka government rejected each of these principles during the second set of meetings at Thimpu. Sri Lanka's response was that a right to self-determination applies only to colonial peoples striving for independence from foreign domination and that that kind of paradigm was not applicable to the Tamil problem in Sri Lanka. The government in its response emphasised that it rejected the concept of a Tamil homeland in all its manifestations. Under the Accord July 29, 1987, the Tamil homeland concept for the Northern and Eastern Provinces received recognition. The homeland concept recognises a Tamil social, cultural and linguistic relationship with the Northern and Eastern Provinces of Sri Lanka.

The whole Thimpu exercise for the Tamil Separatists was a mere rehearsal. They where happy that their prediction to the Indian Government that the talks would produce nothing and their obvious reluctance to participate were all vindicated.

Amirthalingham's letter of December 1, 1985

Looking back at Thimpu, it may be said that neither of the parties to the meeting neither the Sri Lanka government nor the Tamil separatists - were prepared to provide any serious proposal for a settlement. The Sri Lanka government was more or less seeking some ideas from the separatists, while the latter were taking the position: Tell us what you will give and then we will tell you whether that is sufficient for our needs. As an attempt to forge a dialogue, Amirthalingam as the Secretary of T.U.L.F. and Sivasithamparam as the President of the T.U.L.F. decided to write to Gandhi, putting forward proposals which the Sri Lanka government might consider. This was done in a letter to Gandhi dated December 1, 1985. The letter contained four annexes and was in four parts running to thirty-four pages. It proposed several issues for discussion; of these the predominant issue was the Tamils' claim to a homeland. Within this framework, Amirthalingam claimed devolution of power in areas of law and order, administration of justice and the courts, the police force and a sundry of other domestic matters. In addition and as part of the homeland concept Amirthalingam claimed a union between the Northern and Eastern Provinces as constituting one single Tamil linguistic area. He asked for restrictions on the power of Parliament at Jayawardenepura (Colombo) in legislating in matters concerning minority affairs. He asked for Tamil to be made an additional official language of Sri Lanka. Amirthalingam further asked for the observance of the general ethnic proportions in the country while recruiting to the Sri Lanka Armed Forces. As a matter of constitutional arrangement, he asked for the appointment 
of a Chief Minister, elected by the people, for each of the devolved units and the appointment of a Governor to administer the Province. The latter of ficial Amirthalingam wanted to be an appointee of the President. Lastly Amirthalingam wanted special provisions for the establishment of radministrative districts ' for 'Tamils of recent Indian origin', which meant the Estate Indian Tamil labour force. These administrative districts, Amirthalingam argued, would enable these new Tamils to enjoy a sense of security and help manifest their participation in the political movements and in governments found on the island.

It is very important to emphasise that both Amirthalingam and Sivasithamperam reiterated in their letter that all these proposals were in no way intended to do violence to the unitary concept upon which the constitution of Sri Lanka rests. This re-affirmation of the unitary state is something that the T.U.L.F. in 1985 appears to have undertaken on their own. The militant separatists groups pursuing Eelam were clearly against that concept; they wanted a separate state.

\section{Political Parties Conference, 25th June, 1986}

During the first half of 1986 private discussions between the U.N.P. and the T.U.L.F. continued unabated. Neelan Tiruchelvam the former M.P. for Vaddukodai and a leading member of the T.U.L.F. was available in Colombo. He had acquired both the respect and trust of the government and others in Sri Lanka's varied and complex political circles. A fresh approach to the ethnic problem was now considered to be long overdue. The Sri Lanka government in the meantime had announced that it was extending Sri Lankan citizenship to 94,000 Indian Tamils and their legitimate off-spring amounting to a total of some 150,000 . The declaration was itself a sufficient indication to the Indian government that the Sri Lanka government was able to take unpopular decisions, despite the objections of the majority Sinhala-Buddhists and the Buddhist clergy. The citizenship issue of the Indian Tamils was a thorney one for the majority Sinhalese. By April, the Indian government was ready for another round of talks and, on April 30, 1986, Gandhi sent his then Deputy Minister of Internal Security, K. Chidambaram - a Tamil himself from the Southern State of Tamil Nadu - to meet with Jayawardene, in Colombo. Chidambaram, however, carried a heavy baggage of material for Jayawardene on the importance of Provincial Councils as an instrument for the settlement of the ethnic problem. Having been convinced of the need for a devolution of power along the lines of Provincial Councils, Jayewardene summoned a specially assembled group on the 25th June, 1986 which he called the Political Parties Conference (P.P.C.).

The P.P.C. differed from the A.P.C. of 1984 in at least three aspects. First, the P.P.C. did not include religious or special interest groups. One of the major problems the A.P.C. faced was the often inconsistent views that special interest groups and various religious bodies placed before the A.C.P. - views which often sidetracked and diminished the importance and the intensity of other discussions. Those religious and special interest 
groupes kept in touch by personal communications, and their views were sought by the President during the exercise despite their absence from the P.P.C. meetings. Second, the S.L.F.P. and the T.U.L.F. were not participants at the P.P.C. These two political parties decided on the own to keep away from the deliberations. However, Mrs. Bandaranaike, as the leader of the S.L.F.P., personally met Jayawardene for discussions and subsequently provided him with a written response concerning the proposal for Provincial Councils. Both these parties were at some time or another participants in the A.C.P. of 1984. Third, the P.P.C. was not summoned to obtain a consensus as in the case of the A.P.C. The P.P.C. was to hear the proposals and thereafter make their response in strict confidence to the government. Speed in the proceedings was the key; the government intended legislation to follow without delay. The refusal of the T.U.L.F. to attend the P.P.C. was supplemented by Gandhi summoning the T.U.L.F. leaders to New Delhi. There the T.U.L.F. leaders were briefed by Gandhi's Foreign Secretary, Shiv Shankar. India gave the T.U.L.F. leaders a clear understanding that the Sri Lanka government was not prepared to proceed any further; the Provincial Councils to be established along existing boundaries was its bottom line. India further informed the T.U.L.F. that in spite of any objections the T.U.L.F. may have, India would like the T.U.L.F. to consider the Provincial Councils as a basis for negotiations. On the 13th of July, 1986, the T.U.L.F. members left Madras for Colombo to meet president Jayawardene for the first time since December 1984. In the meantime, India had shown the proposals to the militant group with a clear understanding that that was the bottom line. On the Indian side, pressure was beginning to mount both against the T.U.L.F. and the militants to accept the proposals as a basis for a settlement. It was therefore becoming progressively clear that Indian participation in any settlement was necessary. At this point, in July, 1986, it was clear that India was willing to throw her support behind the Sri Lanka proposals.

What then were these proposals? They provided for three levels of government. First, the central government which would be responsible for defence, foreign affairs, monetary policy, postal services, customs, foreign trade, immigration, ports, aviation, broadcasting and communication. Second, the provincial governments were to be established with their territorial boundaries based upon existing provincial boundaries. These provincial governments would be responsible for agriculture, industry, education, land settlement, internal law and order and the administration of justice. There would be an elected Chief Minister and a Governor appointed by the President for each Province. Under these proposals, the President had the power to intervene in the affairs of the Provincial councils if, in his judgment, the Councils were not being conducted according to their constitution or to any applicable law. The right to interfere would be exercised by the President, either by introducing fresh policies or by dissolving the Council itself and subjecting it to presidential rule. At the third level of government there would be Local Bodies engaged in local government and therefore in line with Urban and Municipal Councils as established by law. 
It is important to point out that these proposals did not call for the amalgamation of the North and the East at the Provincial Council level and that India was willing to back them despite the perceived objections of both the T.U.L.F. and the militants. By the end of July 1986, the Sri Lankan Government was clearly in a position to implement these proposals, but it found itself beleaguered by the sustained pressures applied by a combination of forces. The Sinhala people, the Buddhist priests and the S.L.F.P. opposed these proposals in a most powerful manner. They each pointed out that these would ring the death knell of the Sinhala race. Jayawardene found opposition from within his own party, and between July 1986 and July 1987 the Sri Lankan Government allowed the situation to drift - but for one significant event in December 1986.

Indo-Sri Lankan Meeting of December 19th, 1986.

By the middle of December 1986 both the Sri Lanka Government and the Indian Government were agreed on a solution based on the Provincial Council. They were both agreed that pressure should accordingly be brought to bear upon the T.U.L.F. and the separatists. By the middle of December it became apparent that the differences between the Tamils and the Sri Lanka Government could be distilled into the issue of linkage. The Tamils wanted the Northern and the Eastern Provinces linked into one whole region while the Sri Lanka Government wished to keep them separate. The Sri Lankan proposed two possible alternatives. First, it proposed the linking of the two provinces at the institutional level. This meant that certain common services be established to implement legislation voted by two separate Provincial Councils. This proposal helped the two Provincial Councils to function separately but in certain specified areas such as education, health, social services common institutions could be established to implement these policies. Second, if the first was not acceptable, the Sri Lanka Government proposed the detaching of the district of Amparai from the Eastern province so that the Tamil percentage in the East would rise to $48 \%$ as opposed to the $331 / 3$, if Amparai was kept as a part of the Eastern Province. That would give the Tamils a better than even chance of forming the government in the Eastern Province.

The L.T.T.E. (Liberation Tigers of Tamil Eelam) guerrilla group which had gained dominance in both the North and the East disagreed with this second alternative. The L.T.T.E. argued that the Amparai District which encompasses 1752 sq. miles (4485 sq kms.) comprises four electorates: Amparai, Pottuvill, Kalmunai and Samanthurai. About half the Amparai district is settled by Sinhala people while the rest of the district is settled predominantly by Muslims and some Tamils. Further, the L.T.T.E. argued that $90 \%$ of the land in the Amparai electorate (which is occupied largely by Sinhala) is irrigated by the Inginiyagala scheme and therefore was extremely fertile. Detaching such a valuable piece of real property would harm the Eastern Province. The L.T.T.E., however, made the almost impossible request to de-Sinhalise the district of Amparai and then leave it as a part of the Eastern Province. In any event, the L.T.T.E. expressed 
grave reservations about the entire proposal. By the 27th December, 1986, the Sri Lanka Government gave its response to the Indian Foreign Secretary. It was in no way an outright rejection, but it certainly made clear to the Indians that linking Northern and Eastern Provinces was a sticky point and, indeed, the central issue that was blocking a settlement.

During the early months of 1987 , the talks were becoming deadlocked, but India was insisting upon the proposals of December 19th becoming the foundation for a settlement. Guerilla activity was now heating up and, on April 17 and again on April 21, guerilla activity killed as many as 175 persons in attacks against buses and a car bomb explosion in the centre of the city of Colombo. The Sri Lanka government responded by waging open war against the guerillas in the North including aerial bombardments upon guerilla bases in the Jaffna Peninsula. India responded with unconcealed anger, first by sending a flotilla of boats laden with what the Indian gouvernment claimed to be much needed food aid on June 3, and then by air-dropping the aid on June 4. The flotilla of boats were intercepted by the Sri Lanka Navy and sent back while the air drop was considered as a gross violation of Sri Lanka's sovereignty and a breach of international law. These two events undoubtedly formed the political fulcrum around which other events then began to move.

India's insistence that the Tamils in the Northern Province were on the point of starvation was repudiated by the Sri Lanka government, which offered to fly in Indian High Commission personnel on an inspection tour. This invitation was turned down by the Indian High Commission in Colombo. However, on June 25 and on several subsequent days, the Sri Lanka Government agreed to admit Indian ships carrying food aid to the northern port of Kankesanturai, which was then firmly in Sri Lankan hands. With the participation of the L.T.T.E. the food distribution was carried out. For the L.T.T.E. held the distribution lines.

This relief operation may well have been an essential element of the Indian strategy, to let the Sri Lankans know that, if need be, India had the intention of intervening. It was unnecessary to make the point that the Indians had the ability to intervene, for their Southern command poised in Tanjavur Air Base was only several minutes' flying time from Sri Lanka's northern airport of Pallay. The Indian air drop therefore was a warning to the Sri Lankan government. The international reaction to it was both muted and weak. The Sri Lankan government therefore felt abandoned by almost everyone, particularly by the western powers. Protests were heard only from the members of the South Asian Association for Regional Association (S.A.A.R.C.). There too it was from Pakistan, Bangladesh, Nepal and the Maldive Islands. Bhutan remained muted. Sri Lanka herself a member of the S.A.A.R.C. was being invaded by a fellow member, India. A matter of considerable regret meriting grave international concern. The S.L.F.P., Sinhalese, the Buddhist priests and now a new and perhaps more dangerous element, the Sinhala ultra left guerrillas, the Jathika Vimukthi Peramuna, had all declared their opposition to any settlement based on Provincial Councils. As late as July 
10th, a leading Buddhist monk in the Sinhala-Buddhist struggle expressed the view that he would oppose any movement beyond the District Development Councils. This bears clear testimony to the absence of any reality as to what exactly was the nature of the ethnic problem. The idea of District Development Comments as an instrument for the settlement of the ethnic problem was thought to have ended with the loss of the six ballot boxes in the Jaffna Peninsula in 1980.

On July 17, the President, the Minister for National Security and the Minister for Lands and Land Development met with the Indian High Commissioner to explore a new proposal. The Indian High Commissioner Dixit allowed no time to pass unutilised thereafter. He himself left for New Delhi on July 18 while instructing a senior member of his mission to fly to Jaffna and meet with Prabhakaran, the leader of the L.T.T.E. guerrilla group who remained holed up in his bunker. Dixit himself briefed his superiors on the urgency of the matters concerned in Jayewardene's letter to Rajeev Gandhi. On June 19th, the Foreign Office sent a high level spokesperson from New Delhi to Madras to brief the separatist groups. In the meantime New Delhi prepared to have all the Tamil groups including Prabhakaran and the T.U.L.F. brought to New Delhi for a final confrontation. Prabhakaran himself was plucked out of his Jaffna hide-out by an Indian helicopter and was carried to Madras and put on an Indian passenger airliner to New Delhi. Troughout his stay in India, the Indian government kept him incommunicado, guarded by the ferocious black cats - a crack Indian anti-terrorist batallion. On the 22nd July Dixit returned to Colombo and continued to talk to Jayewardene. Jayewardene himself managed to convince his cabinet and his party caucus to accept the proposals by July 24 th and on that date announced to the country that an agreement had been reached on a peace plan with the Indian government and that an accord between the two states regarding this plan would be signed on the 29th July 1987 in Colombo. The Sri Lanka government provided no further details about the plan and left the details to be filled in during the next few days through gossip, rumour and wild speculation.

The Accord of July 29th, 1987.

Commencing from July 24th, 1987, the Indian government conducted protracted talks with the T.U.L.F. and all other Tamil separatists groups in New Delhi. Those talks were targeted towards explaining the proposed accord and obtaining their consent. As Prabhakaran explained at a public meeting on a later date, the Indian government gave the Tamil groups no opportunity to discuss and make any counter-proposals. The accord contained everything that there was to be contained in the settlement. The Tamils had no option but to accept them. Equally, the Sinhalese had no option either. There was not going to be any parliamentary debate upon the accord nor would there be such futile meetings like the All Party Conferences and Political Party Conferences. India had told Prabhakaran and the rest that, whether they liked it or not, the Indian government was proceeding to sign the accord and implement it with the Sri Lanka government - and 
that was all there was to it. The accord was signed by the Prime Minister of India and by the President of Sri Lanka, exercising their powers as chief executives of the two sovereign states of India and of Sri Lanka. However, any subsidiary legislation that may become necessary so as to implement them would go before Parliament for approval. The opposition to the Accord in Sri Lanka took several forms. The Buddhist Priests performed Satyagraha, or passive resistance, while the members of the S.L.F.P. marched in the streets of Colombo under banners and shouting slogans. The extreme left - the J.V.P., spearheaded by the University students are believed to have destroyed public property in the amount of some 4.2 biilion rupees (200 million Canadian dollars) and in the midst of these some twenty-five academics publicly supported the Accord. Gandhi arrived in Sri Lanka at 10:50 in the morning of Wednesday the 29th July, 1987 and proceeded to sign the Accord at 3:37 p.m. on the same day. Certain numerologists have found the time of signing most inauspicious. The numbers add up to a total of 13 . In contrast almost a week later the L.T.T.E. surrendered their first weapon - a pistol at 4:10 p.m. The numbers add up to a lucky 5. Some notable absentees at the signing ceremony were the Prime Minister - Premadasa and the Minister for National Security - Athulathmudali. Athulathmudali, however, was reported to have had had a 20 minute meeting with Gandhi on the 29th night. Gandhi left Sri Lanka at 11:00 a.m. on 30th July after successfully avoiding an assassination attempt by one of the Sri Lanka Navy honour guards. It was later revealed that his imported bullet proof vest had saved him, the vest having taken the brunt of the blow aimed with the guard's rifle butt. All of the ceremonies attending the signing of the accord were executed four hour continuous, island-wide curfew.

What constitutes the accord? The core element of the accord is to be found in Article 2:15, which reads:

"These proposuals are conditional to an acceptance of the proposals negotiated from 4.5.1986 to 19.12.1986."

Those negotiations now characterised as the 'December 19th, 1986 proposals did not contain any agreement for the linking of the Northern and the Eastern Provinces on the island. The linking of the two provinces appears to have been added to the 'December 19, 1986 proposals' by Article 2.2 of the accord:

"During the period, which shall be considered an interim period, (i.e. from the date of the elections to the Provincial Council as specified in - to the date of the referendum as specified in -) the Northern and Eastern Provinces as now constituted, will form one administrative unit, having one elected Provoncial Council. Such a unit will have one Governor, one Chief Minister and one Board of Ministers".

Articles 2.15 and 2:2 together provide the foundation for the accord. The link between the Northern and the Eastern Provinces was made subject to a referendum. This referen- 
dum was to be held at any time before December 31, 1988. The referendum was limited to the inhabitants of the Eastern Province, to determine whether they wished to remain linked to the Northern Province or whether they wished to remain as a separate entity. This choice to uncouple from the single entity was not available to the inhabitants of the Northern Province. The choice is for the Easterners to separate from the Northerners. This is contained in Article 3 of the accord. As all referenda, this referendum too is subject to the requirement of a simple majority. This is stated in Article 2.6 of the accord. But under a proviso to Article 2.3 of the accord it is declared that:

"The President may, at his discretion, decide to postpone such a referendum."

The whole question of linking the North and the East raises several political and emotional problems. For the Tamils, the link of the two provinces is regarded as vital for their own economic security. For the North, left alone with a $99 \%$ Tamil population, is not economically viable. The East, with $331 / 3 \%$ of the Tamil population, when joined gives a comfortable Tamil majority in the combined territory and in addition access to fertile agricultural land in the Eastern Province. This is one reason. The second reason is that the Tamils in the North and the East of the island have become accustomed to the claim that these territories constitute their traditional homeland. The idea of a traditional homeland had been advocated by the Tamils from ancient times. But it was not recognised in the 'December 19, 1986 proposals and this is yet another matter that the accord by Article 1.4 adds to the original 'December 19, 1986 proposalsı. Article 1.3 declares that:

" - the Northern and the Eastern Provinces have been areas of historical habitation of Sri Lankan Tamil speaking peoples, who have at all time hitherto lived together in this territory with other ethnic groups."

For the Sinhalese, the linkage raises different problems. The Sinhalese view the link plus the recognition of that area as a part of the Tamil claim for a traditional homeland as constituting 'Eelam‘. 'Eelam ' has what the Tamil guerillas were fighting for. Eelam - a Tamil word means an independent sovereign state. The claim for the establishment of Eelam encompassed both the Northern and the Eastern Provinces. The linking of the two provinces under the accord, now, and declaring them as "Nija-bhumi " or traditional homelands, provide an unacceptable situation for the majority Sinhalese. There is also a second reason. The Northern and the Eastern provinces together form almost three-fifth of the coastal area of the island. The argument is made that less than $20 \%$ of the population will thereby receive control of more than $60 \%$ of the maritime resources. There is a third objection raised by the Sinhalese. There are over forty different religious sites venerated by the Buddhists which lie within the Northern and Eastern Provinces. Of these a large majority may be found in the Eastern Province. The majority of the Sinhalese are Buddhists. The Sinhalese fear that these places of worship may be neg- 
lected and in years become derelict under successive Tamil administrations. There are Christian places too that lie within those two provinces, particularly, the Church of Our Lady of Madhu. But many Tamils are Christians and no Tamils are Buddhists. Therefore the risks of places of Christian worship being neglected by a predominantly Tamil administration, the Sinhalese believe, are much less than for places of Buddhist worship. The whole idea linkages among provinces having common cultural, ethnic and other relevant characteristics is new and did not figure within the 'December 19th, 1986، accord. The ability to link is available to all nine provinces on the island and is not a power which is limited to the North and the East. In Article 2.1, the accord states:

"Since the Gouvernment of Sri Lanka proposes to permit adjoining provinces to join to form one administrative unit and also by a Referendum to separate as may be permitted to the Northern and Eastern Provinces -."

Relying on this Article, President Jayewardene expressed the view in a television broadcast on the 31st July that he hoped to link, besides the Northern and the Eastern Provinces, the Central, Uva and Sabaragamuwa. These three provinces once formed the former Kandyan Kingdom - until it was annexed by the British in 1815 to form the Crown of Colony of Ceylon. The Sinhalese view this proposal with trepidation. They say that it creates a dangerous precedent. They fear that the large and growing Indian Tamil community in the plantation sector in Uva might at some future date grow in sufficient numbers to win a referendum to join the adjoining Eastern Province. Such a link could help to carve out one whole area of Tamil domination which might threaten the very existence of the Sinhalese as an ethnic group.

The 'December 19th, 1986 proposals' said nothing about the official language of Sri Lanka. They did recognise that the Northern Province might declare Tamil as the language of administration of that province. As for the Eastern Province, the adoption of Tamil as the language of administration was a distinct possibility under the December 19, 1986 proposals. But the official language of the island even under those proposals was expected to remain as it was declared in 1958 - Sinhala. The accord by Article 2.18 alters that and adds another item to the 'December 19th, 1986 proposals'. That Article reads:

"The official language of Sri Lanka shall be Sinhala. Tamil and English will also be official languages."

The use of three official languages entails many logistical difficulties and much expense. Canada regognises French and English as twin official languages. Difficulties experienced in Canada in implementing this policy are legion.

The 'December 19th, 1986 proposals' were clear as to what powers the Provincial Councils would receive. They were clearly spelt out in the proposals as those which the Indian States enjoy under the Indian Constitution. In Schedule VII of the Indian Consti- 
tution there are three parts - List I, List II and List III. List I contains the powers of the Union Gouvernment at the centre. List II contains State Powers and List III contains concurrent powers - shared between the States and the Union. The best constitutional lawyers of the land have said that, from the first administration of Independent India under Nehru and right up to both Gandhis, mother and son - the concurrent powers stated under List II have scarcely been concurrent. They have also been usurped by the centre to be used as if they belonged to List I. This naturally meant that the States were limited to powers mentioned in List II. The Indian States were, therefore, subject to the overwhelming powers exercised by the Union Gouvernment in New Delhi - to the extent to which State Governments have often been dismissed and subjected to 'Presidential ruler from New Delhi. All these are incumbent in the 'December 19th, 1986 proposals' which the Indian government had accepted as a basis for a settlement. In accord does not state what powers the provinces shall receive. The government has promised a draft bill before December 1987, which presumably will state those powers.

The accord places some considerable responsibilities upon the Indian government. These are detailed in Article 2.16 of the accord which reads as follows:

(a) India will take all necessary steps to ensure that Indian territory is not used for activities prejudicial to the unity, integrity and security of Sri Lanka.

(b) The Indian Navy/Coast Guard will co-operate with the Sri Lanka Navy in preventing Tamil militant activities from affecting Sri Lanka.

(c) In the event that the Government of Sri Lanka requests the Government of India to afford military assistance to implement these proposals the Gouvernment of India will co-operate by giving to the Government of Sri Lanka such military assistance as and when requested.

(d) The Government of India will expedite repatriation from Sri Lanka of Indian citizens to India who are resident there, concurrently with the repatriation of Sri Lankan refugees from Tamil Nadu.

(e) The Governments of India and Sri Lanka will co-operate in ensuring the physical security and safety of all communities inhabiting the Northern and Eastern Provinces.

These provisions will permit the government of Sri Lanka to request Indian military intervention under (c) above. Under that clause, the Sri Lanka government one day after signing the accord requested and indeed did receive Indian military assistance to disarm the guerillas and ensure that their weapons were surrendered to the Sri Lankan government forces. However, under clause (e) of the accord the government of India has a power to maintain an Indian army presence in the North and the East to co-operate with the Sri Lankan forces "in ensuring the physical security and safety of all communities inhabiting the Northern and Eastern Provinces". The involvement of the Indian naval forces under the accord is expected to be an continuing obligation. Under clause 
(b) of the accord, the Indian naval forces are to collaborate with the Sri Lankan navy in preventing illegal excursions across the Palk Straits. Two further obligations that the government of India has assumed are to prevent Indian territory being used for acitivities which are antithetical to the interests of Sri Lanka and an obligation to expedite the repatriation of nearly 150000 Indian estate labour who had several years ago opted for Indian citizenship.

The accord, also, dealt with several other matters of more minor import. It dealt with the granting of amnesty to the guerillas, the release of prisoners held under the Prevention of Terrorism Act, the extinguishing of states of emergencies in the North and the East, the surrender of weapons by the guerrillas and the withdrawal of Sri Lankan forces from the Northern and Eastern provinces. The accord carried an 'Annexe to the Agreement which requires some comment.

The Annexes place certain restrictions on the conduct of foreign policy by the Sri Lankan government. It limits the power of the Sri Lankan government to employ foreign military and intelligence personnel, if such an engagement may appear to be prejudicial to "Indo-Sri Lanka relations". There is no such limitation placed on India's ability to conduct her foreign relations in this area or in other areas mentioned with specificity in the Annexes. The use of the port of Trincomalee or any other port on the island is restricted to such use as will not affect Indo-Sri Lankan relations. There is no concurrent responsibility placed on India about her use of her ports. Aimed specifically at the agreement reached in 1980 with the United States of America establishing in Sri Lanka a transmitting station for Voice of America, was the following paragraph in the Annexure:

"Sri Lanka's agreements with foreign broadcasting organizations will be reviewed to ensure that any facilities set up by them in Sri Lanka are used solely as public broadcasting facilities and not for any military or intelligence purpose".

These limitations placed upon the foreign policy objectives of Sri Lanka are complemented by India's acceptance of two responsibilities which are of importance to the Sri Lankan government. That part of the Annex reads:

"In the same spirit, India will:

(i) deport all Sri Lankan citizens who are found to be engaging in terrorist activities or are advocating separatism or secessionism.

(ii) provide training facilities and military supplies for Sri Lankan security forces."

These two obligations are clearly double-edged. The observance of the first obligation will certainly prevent a recurrence of the military activities of the past four years (1983-1987). If the Sri Lankan government were to renege on their side of the bargain then the Indian government may lawfully allow their territory to be used for launching 
attacks on Sri Lanka, both military attacks and political conspiracies. This will return the island to the chaos of the last four years, a terrifying thought for any future Sri Lankan administration. Military training and supply of hardware is in the distinct interest of India, for the Sri Lankan army will thereby become psychologically oriented towards accepting India as their military guru. This is in addition to the obvious dependence of Sri Lanka upon the use of Indian military hardware; a factor of some economic importance to the Indian armaments industry. It must again be stated that none of these Annexes were a part of the proposals made on December 31, 1986.

\section{Reflections on the Accord}

Third World post-colonial conflicts have in most instances sprung from explosive ethnic conflicts. The Nigerian Civil War - a war between the Ibos versus the rest - or the recent Fijian Conflict - the Fijians versus the Indians could all be traced back to some ethnic problem. The First World on the other hand has successfully avoided open ethnic conflicts by sophisticated political manoeuvres. Belgium avoided an open confrontation between the Waloons and the French by introducing changes into the language provisions of the Constitution. The Spanish are still trying to work out some accommodation with the Basque nationalists. The British gave the Welsh and the Scottish an opportunity to establish their regional assemblies - but this was turned down by the people at a referendum. The failure of the U.K. government in Northern Ireland is perhaps symptomatic of the hard line taken by successive administrations in Westminster to protect the rights of the Protestants. The Canadians, perhaps took the most radical step by holding a referendum on the possible separation of Quebec from the Dominion of Canada in 1982. The Quebecois rejected separation with a 3.2 vote. One of the hallmarks of the Canadian referendum was that it gave the Province of Quebec a democratic choice to separate. What Third World country would hold a vote for separation? What Third World country is capable of taking the view that the then Canadian Prime Minister Trudeau took of minority rights. Addressing a mammouth rally in Quebec, on the eve of the referendum, Trudeau declared:

"In human history ethnic group rights cannot be weighed upon fine scales as if they were precious metal bought and sold by merchants in a Bazaar. We need to put down firm roots for a new national edifice, where all Canadians: Anglophones, Francophones, Natives and all, may live together with respect and in harmony. If some have to give a little more and others must take al little more, so be it. For the ultimate goal must inevitably be, not to question as to who got more or who got less. But what kind of society have we thereby built for us, our children and for all Canadians that come af ter us. This is our goal as a government. And I am certain that yours is also the same".

Canada won the referendum. The separatists lost the opportunity to cut Canada into two parts. 
The Indo-Ceylon Accord introduces a new element in the settlement of ethnic conflicts. It introduces the intervention of states in the process of maintaining ethnic harmony outside their borders. There are many parallels to be drawn with contemporary international relations. The intervention of Syria in the affairs of Lebanon to maintain peace between the Muslims and the Maronite Christians is a current example. There must surely be some limitation to this right to intervene or else international law may be providing a foundation for international lawlessness. The intervening power must find a nexus - ethnic or political - between itself and the ethnic conflict outside its borders. The Sri Lankan conflict, in this sense, finds such a nexus - between the Tamil people of Sri Lanka and a similar group that inhabits the Tamilnadu State of India. A similar nexus may be found between the Muslims of Lebanon and the body politic of Syria. There is a second limitation that must be observed. The sovereign power of the state in which the ethnic conflict persists must seek the intervention without pressure. Unless that tacit consent is forthcoming, the intervention is truly against customary international law. The intervention of Syria in Lebanon and the intervention of the Soviet Union in Afghanistan have been with the tacit consent of the governments of those two countries. If justification is required by international law, the intervention of India in Sri Lanka may be founded upon the accord and upon the express invitation extended by President Jayewardene to Rajeev Gandhi to send in his troops. This was done on July 30th, 1987. Jayewardene found that between 29-30 July, the Southern Province had erupted into a state of insurrection. His invitation to the Indian army was accompanied by a request that the Indian Government provide the Indian aircraft ferrying their troops to Jaffna and to have the Sri Lankan troops in the North sent to Colombo. These troops were needed to guard the Southern Province against Sinhala violence as a mark of opposition to the accord. In this sense it may be said that under international law, despite the earlier history of Indian complicity in the troubles in Sri Lanka, Indian intervention was justified and therefore does not constitute a breach of international law. For international law does not require parliamentary consent for a president with executive powers to invite intervention. The 1978 Constitution of Sri Lanka gave President Jayewardene such executive powers.

Compared with that assessment of international law, the intervention of Turkey in Cyprus was against international law, but not the intervention of the Soviet Union in Afghanistan. While Turkey was never invited by President Markarios of Cyprus to intervene in Cyprus in 1974, President Babarak Karmal of Afghanistan invited the Soviet forces in 1979 to help quell the insurrection by the Mujaheedeens there.

The question is always asked whether the interventions would readily cease whenever the consent once given by the sovereign power is withdrawn. In international law whenever the sovereign power that consented to the intervention requires the intervention to cease it should cease and the armies of the intervening powers should withdraw. The problem one sees in the Sri Lankan accord is that the accord requires under at least two conditions the permanent participation of the Indian armed forces in the affairs of the island: 
First, in policing and patrolling the Palk Straits and second win ensuring the physical security and safety of all communities inhabiting the Northern and Eastern Provinces of Sri Lanka". The political weakness of the accord which might in the future prove troublesome is the fact that under the Indo-Sri Lankan accord Indian intervention in the affairs of Sri Lanka may prove to be a permanent feature which might raise the ire of future Sri Lankan administrations and indeed of the people of that island.

The point has been made above that earlier proposals, particularly the one made on December 19, 1987, could have provided the island with the same result without some of the unsavoury conditions contained in the accord. The separatists opposed those proposals and they now are equally against the present accord. India supported the December 19th, 1986 proposals and similarly supports the accord. The majority Sinhala people are against the present accord and they were indeed against all previous proposals. The question is now asked as to why the government of Sri Lanka did not proceed to implement the December 19th, 1986 proposals with the help of the Indian government in the same way as it did the accord. That is without reference to the people or to Parliament. The answer perhaps lies in the psychology of the president. As from 1983 every proposal that the government made for a settlement was bitterly opposed by the Sinhala Buddhists majority and by the Buddhist clergy. It became evident by June 1987 that the polarisation against the government was so entrenched that President Jayawardene would never have succeeded in obtaining the consent of the Sinhala people for any reasonable accommodation with the Tamil separatists which went beyond the District Development Councils, a proposal of some considerable antiquity. Even in July 1987 the Buddhist clergy were saying: "D.D.C.s and no more". In addition to this atmosphere of non co-operation with the government, President Jayewardene, as the Commander-inChief of the armed forces, may have recognised the military weakness of the government forces. By June, the government forces were able to hold no more than 30 square miles of the Jaffna peninsula which was no more than $20 \%$ of the total land area of the Northern Peninsula. Thirdly, the Indian intervention in June of Sri Lanka's airspace to parachute some unwanted bundles of food and the re-establishment of a powerful southern command in Tanjavur on the southern tip of India caused some anxiety to the government in Colombo, of a possible Indian military intervention - similar to that in Bangladesh in 1972 - which would then forever establish a separate Tamil state in the Northern and Eastern province - achieving Eelam. In the face of this the government of Sri Lanka may have decided that the time was ripe to strike a deal with India, directly, and save the unitary state structure. At all costs it was in Sri Lanka's interest to prevent a military defeat paving the way for a separate state of Tamil Eelam. Perhaps it was President Jayawardene who alone knew how militarily weak Sri Lanka's position was.

The lesson to be drawn by the Sinhalese from this political misadventure is that national pride should sometimes be compromised for the sake of reality. The reality was that in a geo-political sense India was indeed the stronger power. So long as India was backing the separatists and this was clear to everyone, the strength of the separatists was the 
strength of India. Inasmuch as Sri Lanka was in no way equipped to fight the Indians, India would never have allowed the separatists to be defeated in their quest for Eelam, without obtaining some accommodation from the Sri Lankan government which would at the same time at least maintain, if not enhance the popularity of the Congress Party (Indira) among the people and the government of Tamil Nadu. This indeed was a reality. Rajeev Gandhi needed the support of the southern state of Tamil Nadu, with its 50 million Tamil speaking people. The position, therefore, ought to have been clear that when there was the first opportunity for an agreement acceptable to India it was in the best interest of Sri Lanka to conclude it. That would have brought about, as it did now, an immediate end to the fighting. The first opportunity arrived in 1983 with the proposals hammered out with Parathasarthy. The majority Sinhalese opposed those proposals tooth and nail as they did every subsequent proposal including the accord. The last opportunity was found in the Decemter 19th, 1986 proposals. They too were unceremoniously discarded. Considering the proposals in sequence, from the Parathasarthy proposals of 1983 through to the December 19th, 1986 proposals and to the present accord, it will be seen that each new attempt for a settlement gave the Tamils more and the anger and the strength of the Sinhala opposition grew accordingly.

The present accord, therefore, is not the best for the country. But it must be regarded as the one that stopped the next proposal from forming a basis for a settlement. The next proposal, as history has shown, would surely have been worse that the present accord. If no settlement had been reached, there presumably would have been an Indian military intervention or an outright victory by the Liberation Tigers of Tamil Eelam establishing the new State of Tamil Eelam. The Indian government would never have allowed an outright Sri Lankan victory. That could well have caused the secession of the State of Tamil Nadu from the Union of India. And if that were to happen, the new State of Tamil Nadu would certainly have invaded Sri Lanka. That was a reality. The accord may well have prevented that event. And if the Sinhalese feel that they have been betrayed by a government which they put into power, not so long ago, then they must take the blame for failing to comprehend the reality that the Tamil separatists, with the backing of India, would never have short-changed their position for an outdated and a largely non-functional District Development Council, which was the farthest point to which the Sinhala majority was prepared to go.

\section{A Postscript}

Between September 21 and October 9, 1987 nearly 200 Sinhalese were killed in the Eastern Province. These killings were attributed to the L.T.T.E. Among the 200 were a few high-ranking officers of the government. These included the Commander of the Special Task Force (S.T.F.) and the Government Agent for the district of Batticoloa, a principal district in the Eastern Province. The latter particularly aroused the ire of the 
Indian Peace keeping force (I.P.K.F.), for the government officers, at the time of their death were being conducted by jeep under I.P.K.F. protection. In addition this led to the newspapers in Sri Lanka referring to the Indian Peace keeping force as the 'S.C.I.P.K.F.'. The addition 'S.C.' stood for'so called،. By October 9th, 1987, the Indian Government decided to act under the accord by invoking its powers under Article 2.14 and 2.16(c) of the accord. The combined effect of these Articles justified the Indian government's utilising its peace keeping force to launch a military offensive against the L.T.T.E. forces in Jaffna, in particular, and in the Eastern Province in general. The high Indian casualties and the enormous costs incurred by the Indian government in defeating a formidable enemy constitutes a very heavy investment in blood and money for the effective implementation of the accord. Successive Indian governments may consider it justifiable to claim the long term protection of rights reserved for India under the accord. This places a heavy burden upon successive Sri Lankan governments to resist the clamour of the Sinhalese majority to rid Sri Lanka of Indian influence. Many future governments may gain power upon an anti-Indian platform. But the issue that may cause some considerable irritation in the Indo-Sri Lankan relationship may be the extent to which future Sri Lankan administrations may ask for a re-structuring of the accord to minimise if not terminate Indian influence. Upon that issue, as the memories of battles in Jaffna and the killings in the East begin to fade, Indian presence upon Sri Lankan soil might become more and more irksome and the accord less and less important to successive Sri Lankan governments. The accord therefore might at that point mark the commencement of a period of discord between the two countries. Wiser counsel and mature statesmanship at both places - Colombo and New Delhi - might on the other hand prevail. At such a time as when there is the prevalence of peace in the North and in the East, the two powers may even decide to let the accord slip away, like a falling star in a blaze of glory dipping into the Indian Ocean around the Palk Straits.

India holds the key to peace in Sri Lanka. If she wishes to heat the cauldron of conflict in Sri Lanka again, she has only to establish hostile bases in the Southern State of Tamil Nadu and invite another round of guerilla warfare in the land of her southern neighbour. Sri Lanka may now recognise this possibility. She might in addition recognise that in its present geo-political sweep, India has a sphere of influence to contain. For that reason, the non-militarisation of the Port of Trincomalee and the non-involvement of Sri Lanka in Western or Eastern power blocks might be a minimum that India might require Sri Lanka to concede as a reasonable quid pro quo for the re-negotiation of the accord. It is hoped that when the time comes, the two nations will succeed in articulating a new basis for peace, mutual respect and economic co-operation. When negotiating that new relationship one hopes that both India and Sri Lanka might consider not the immediate benefits to the two sovereign nations and their people but the contribution that the new accord could make to the maintenance of peace in South Asia. The present conflict has widened discord in the region - with Pakistan and Bangladesh on one side and India on the other. While Pakistan and Bangladesh have helped Sri Lanka by providing military 
training and by diplomatic support, India had fallen squarely on the side of the separatists. Such an arrangement is bad for the area - with the West, particularly the U.S.A., and the Soviet Union becoming in stages drawn into the conflict. India's principal concerns about the Trincomalee harbour and the location of the Voice of America in Sri Lanka spring out of a fear nearer to her there might arise an antagonistic sphere of interest. These have received particular emphasis in the Annexes to the Accord, in Prime Minister Gandhi's letter of July 29th, 1987. It is therefore necessary that Sri Lanka now becomes sensitised to these concerns and that an accepted framework is formulated for the re-negotiation of the accord, once peace begins to take its hold on the island.

\section{The Accord}

Following is the Agreement signed this afternoon between his Excellency the President of Sri Lanka and his Excellency the Prime Minister of India.

\section{Indo-Sri Lanka Agreement}

\section{To establish peace and normalcy in Sri Lanka}

The President of the Democratic Socialist Republic of Sri Lanka, His Excellency Mr. J. R. Jayewardene, and the Prime Minister of the Republic of India, His Excellency Mr. Rajiv Gandhi, having met at Colombo on July 29, 1987.

Attaching utmost importance to nurturing, intensifying and stengthening the traditional friendship of Sri Lanka and India, and acknowledging the imperative need of resolving the ethnic problem of Sri Lanka, and the consequent violence, and for the safety, well-being and prosperity of people belonging to all communities in Sri Lanka.

Have this day entered into following agreement to fulfill this objective.

In this context.

1.1 Desiring to preserve the unity, sovereignty and territorial integritiy of Sri Lanka:

1.2 Acknowledging that Sri Lanka is a multi-ethnic and a multi-lingual plural society consisting, inter alia, of Sinhalese, Tamils, Muslims (Moors) and Burghers:

1.3 Recognising that each ethnic group has a distrinct cultural and linguistic indentity which has to be carefully nurtured:

1.4 Also recognising that the Northern and the Eastern provinces have been areas of historical habitation of Sri Lankan Tamil speaking peoples, who have at all times hitherto lived together in this territory with other ethnic groups:

1.5 Conscious of the necessity of strengthening the forces contributing to the unity, sovereignty and territorial integrity of Sri Lanka, and preserving its character as a multi-ethnic, multi-lingual and multi-religious plural society in which all citizens can live in equality, safety and harmony, and prosper and fulfill their aspirations: 


\section{Resolve that:}

2.1 Since the Government of Sri Lanka proposes to permit adjoining provinces to join to form one administrative unit and also by a referendum to separate as may be permitted to the Northern and Eastern Provinces as outlined below:

2.2 During the period, which shall be considered an interim period, (i.e. from the date of the elections to the Provincial Council, as specified in para. 2.8 to the date of the Referendum as specified in para. 2.3, the Northern and Eastern Provinces as now constituted), will form one administrative unit, having one elected Provincial Council. Such a unit will have one Governor, one Chief Minister and one Board of Ministers. 2.3 There will be a Referendum on or before 31st December, 1988 to enable the people of the Eastern Province to decide whether:

The Eastern Province should remain linked with the Northern Province as one administrative unit, and continue to be governed together with the Northern Province as specified in para. 2.2 or

The Eastern Province should constitute a separate administrative unit having its own distinct Provincial Council with a separate governor, Chief Minister and Board of Ministers.

The President may, at his discretion, decide to postpone such a Referendum.

2.4 All persons who have been displaced due to ethnic violence, or other reasons, will have the right to vote in such a Referendum. Necessary conditions to enable them to return to areas from where they were displaced will be created.

2.5 The Referendum, when held, will be monitored by a Committee headed by the Chief Justice, a member appointed by the President, nominated by the Government of Sri Lanka, and a member appointed by the President, nominated by the representatives of the Tamil speaking people of the Eastern Province.

2.6 A simple majority will be sufficient to determine the result of the Referendum.

2.7 Meetings and other forms of Propaganda, permissible within the laws of the country, will be allowed before the Referendum.

2.8 Elections to Provincial Councils will be held within the next three months, in any event before 31 st December, 1987. Indian observers will be invited for elections to the Provincial Council of the North and the East.

2.9 The emergency will be lifted in the Eastern and Northern Provinces by August 15, 1987. A cessation of hostilities will come into effect all over the island within 48 hours of the signing of this agreement. All arms presently held by militant groups will be surrendered in accordance with an agreed procedure to authorities to be designated by the Government of Sri Lanka.

Consequent to the cessation of hostilities and the surrender of arms by militant groups, the army and other security personnel will be confined to barracks in camps as on 25 May 1987. The process of surrending of arms and the confining of security personnel 
moving back to barracks shall be completed within 72 hours of the cessation of hostilities coming into effect.

2.10 The Government of Sri Lanka will utilise for the purpose of law enforcement and maintenance of security in the Northern and Eastern Provinces same organisations and mechanisms of government as are used in the rest of the country.

2.11 The President of Sri Lanka will grant a general amnesty to political and other prisoners now held in custody under the prevention of terrorism act and other emergency laws, and to combatants, as well as to those persons, accused, charged and/or convicted under these laws. The Government of Sri Lanka will make special efforts to rehabilitate militant youth with a view to bringing them back into mainstream of national life. India will co-operate in the process.

2.12 The Government of Sri Lanka will accept and abide by the above provisions and expect all others to do likewise.

2.13 If the framework for the resolutions is accepted, the Government of Sri Lanka will implement the relevant proposals forthwith.

2.14 The Government of India will underwrite and guarantee the resolutions, and co-operate in the implementation of these proposals.

2.15 These proposals are conditional to an acceptance of the proposals negotiated from 4. 5. 1986 to 19. 12. 1986. Residual matters not finalised during the above negotiations shall be resolved between Indian and Sri Lanka within a period of six weeks of signing this agreement. These proposals are also conditional to the Government of India co-operating directly with the Government of Sri Lanka in their implementation.

2.16 These proposals are also conditional to the Government of India taking the following actions if any militant groups operating in Sri Lanka do not accept this framework of proposals for a settlement, namely,

India will take all necessary steps to ensure that Indian territory is not used for activities prejudicial to the unity, integrity and security of Sri Lanka.

The Indian navy/coast guard will co-operate with the Sri Lanka navy in preventing Tamil militant activities from affecting Sri Lanka.

In the event that the Government of Sri Lanka requests the Government of India to afford military assistance to implement these proposals the Government of India will cooperate by giving to the Government of Sri Lanka such military assistance as and when requested.

The Government of India will expedite repatriation from Sri Lanka of Indian citizens to India who are resident there, concurrently with the repatriation of Sri Lankan refugees from Tamil Nadu.

The Governments of Sri Lanka and India will co-operate in ensuring the physical security and safety of all communities inhabiting the Northern and Eastern provinces.

2.17 The Government of Sri Lanka shall ensure free, full and fair participation of voters from all communities in the Northern and Eastern Provinces in electoral process- 
es envisaged in this agreement. The Government of India will extend full co-operation to the Government of Sri Lanka in this regard.

2.18 The official language of Sri Lanka shall be Sinhala. Tamil and English will also be official languages.

3. This Agreement and the Annexure thereto shall come into force upon signature. In witness whereof we have set our hands and seals hereunto.

Done in Colombo, Sri Lanka, on this the twenty ninth day of July of the year one thousand nine hundred and eighty seven, in duplicate, both texts being equally authentic.

Junius Richard Jayewardene

President of the Democratic Socialist

Republic of Sri Lanka

Rajiv Gandhi

Prime Minister of the

Republic of India

\section{Annexe to the Agreement}

1. His Excellency the President of Sri Lanka and the Prime Minister of India agree that the Referendum mentioned in paragraph 2 and its sub-paragraphs of the Agreement will be observed by a representative of the election commission of India to be invited by his Excellency the President of Sri Lanka.

2. Similarly, both heads of Government agree that the elections to the Provincial Council mentioned in paragraph 2.8 of the Agreement will be observed by a representative of the Government of India to be invited by the President of Sri Lanka.

3. His Excellency the President of Sri Lanka agrees that the home guards would be disbanded and all para-military personnel will be withdrawn from the Eastern and Northern Provinces with a view to creating conditions conducive to fair elections to the Council.

The President, in his discretion, shall absorb such para-military forces, which came into being due to ethnic violence, into the regular security forces of Sri Lanka.

4. The President of Sri Lanka and the Prime Minister of India agree that the Tamil militants shall surrender their arms to authorities agreed upon to be designated by the President of Sri Lanka. The surrender shall take place in the presence of one senior representative each of the Sri Lanka Red Cross and the Indian Red Cross.

5. The President of Sri Lanka and the Prime Minister of India agree that a joint Indo-Sri Lankan observer group consisting of qualified representatives of the Government of Sri Lanka and the Government of India would monitor the cessation of hostilities from 31 July, 1987. 
6. The President of Sri Lanka and the Prime Minister of India also agree that in terms of paragraph 2.14 and paragraph 2.16(C) of the Agreement, an Indian peace keeping contingent may be invited by the President of Sri Lanka to guarantee and enforce the cessation of hostilities, if so required.

\section{Exchange of Letters}

President of Sri Lanka

July 29, 1987

Excellency,

Please refer to your letter dated the 29th of July, 1987, which reads as follows:

Excellency,

1. Conscious of the friendship between our two countries stretching over two millenia and more, and recognising the importance of nurturing this traditional friendship, it is imperative that both Sri Lanka and India reaffirm the decision not to allow our respective territories to be used for activities prejudicial to each other's unity, territorial intigrety and security.

2. In this spirit, you had, during the course of our discussions, agreed to meet some of India's concerns as follows:-

Your Excellency and myself will reach an early understanding about the relevance and employment of foreign military and intelligence personnel with a view to ensuring that such presences will not prejudice Indo-Sri Lankan relations.

Trinomalee or any other ports in Sri Lanka will not be made available for military use by any country in a manner prejudicial to India's interests.

The work of restoring and operating the Trincomalee oil tank farm will be undertaken as a joint venture between India and Sri Lanka.

Sri Lanka's agreements with foreign broadcasting organisations will be reviewed to ensure that any facilites set up by them in Sri Lanka are used solely as public broadcasting facilities and not for any military or intelligence purposes.

3. In the same spirit, India will:

Deport all Sri Lankan citizens who are found to be engaging in terrorist activities or advocating separatism or secessionism.

Provide training facilities and military supplies for Sri Lankan security forces.

4. India and Sri Lanka have agreed to set up a joint consultation mechanism to continuously review matters of common concern in the light of the objectives stated in para. I and specifically to monitor the implementation of other matters contained in this letter. 
5. Kindly confirm, Excellency, that the above correctly sets out the Agreement reached between us.

Please accept, Excellency, the assurances of my highest consideration

Yours sincerely, $\mathrm{SD} /-$

(Rajiv Gandhi)

His Excellency,

Mr. J. R. Jayewardene,

President of the Democratic Socialist

Republic of Sri Lanka,

Colombo.

This is to confirm that the above correctly sets out the understanding reached between us.

Please accept, Excellency, the assurances of my highest consideration

(J.R. Jayewardene, President)

His Excellency,

Mr. Rajiv Gandhi,

Prime Minister of the Republic of India,

New Delhi, India. 


\title{
ABSTRACTS
}

Trade Unions in Sri Lanka: Structures and Alliances under the UNP Government

\author{
By Stefan Chrobot
}

Although extremely divided and economically not very successful, trade unions play an important role in Sri Lankan politics. After its election victory in 1977, the new UNP (United National Party) government intended to increase its control over the trade union movement. Through political cooperation with the Indian Tamil minority the integration of vast groups of plantation workers became possible. The influence and relative importance of independent and oppositional trade unions weakened during the early years of UNP government. This concept, however, later failed due to the unsolved problems of the Tamil-speaking minorities and the increasing Singhalese-Tamil conflict. The author analyses the complex structure of the divided trade union movement and the phenomenon of political sponsorship in trade unions. Based on this, the article focuses on the strike in July 1980, the anti-Tamil riots in 1983 and the successful plantation workers' strike in April 1984. The development shows changing alliances within a relatively stable structure. In the recent past, conditions for trade unions have become more difficult as a result of Sri Lanka's increasing internal conflicts.

\section{The Indo-Sri Lankan Accord in Perspective}

\section{By Lakshman M. Marasinghe}

The article traces the historical benchmarks leading to the commencement of separatist action in Sri Lanka. These historical benchmarks deal with both the pre-independence period and of the three decades of independence. The main focus of the paper is on the negotiations for a settlement. These negotiations were conducted mainly between the Sri Lankan government and the principal militant groups with the Indian government initially and subsequently playing a major role in the talks.

The article deals with seven sets of meetings, the seventh leading to the Indo-Sri Lanka Accord of July 29th, 1987. The talks initially encompassed the five main militant groups - the Tamil Eelam Liberation Organisation (TELO), the People's Liberation Organisation of Tamil Eelam (PLOTE), the Tamil Eelam Army (TEA), the Eelam Revolutionary Organisation of Students (EROS), and the Liberation Tigers of Tamil 
Eelam (LTTE). All these varying groups of militants participated during the earlier stages of the talks but the LTTE alone refused to accept the Accord of 1987.

The article in dealing with each of the meetings raises a number of issues that were discussed. It also deals with the proposals and counter-proposals made by each side at the talks. These have been evaluated. The final section of the paper is on the Indo-Sri Lankan Accord.

The child in the political, constitutional and family law of the Lao People's Democratic Republic

\section{By Arno Wohlgemuth}

Almost half the population of Laos - one of the poorest countries of the world - are children under 15 years of age. Young people are gathered under the aegis of the Union of the Lao People's Revolutionary Youth and indoctrinated to serve as future cadres to the country. Children and adolescents enjoy a peculiar constitutional position, as is the general rule according to socialist theory of state and law.

Infant mortality ranks still high with a ratio of 122 stillborn babies per 1.000 deliveries. Life expectancy for males as well as females equals an average of about 50 years. State and party policies towards children and mothers are laid down mainly in governmental programs and Party resolutions, but also in state decrees mostly dating from the times of the monarchy. The applicability of these old laws and regulations under the present people's democratic regime is to be interpreted in the light of Lenin's doctrine on progress from capitalism (in the case of Laos from feudalism) to socialism as varied by the legal principles on continuity of pre-revolutionary legislation in a socialist state. Thus, the Provisional Regulations on democratic freedoms of the people of June 1, 1974 are to be construed accordingly.

Whereas the child's personality has experienced a rather intense attention in the political, educational and cultural sphere, its legal status under public law is quite vague; not so, however, in private law, which, still in post-monarchial Laos has its basic statutary source in the Civil and Commercial Code of 1927/1965 as modified by the current social and political order.

Keeping in mind the double law enforcement system represented on the one hand by law courts and state authorities and on the other by the village or tribal aristocracies, bonzes and families, the civil-law rule never laid claim to overall implementation. Nevertheless, the law on the books provides detailed prescriptions on the minor's role and interests, his rights and duties within a complete or single-parent family unit.

Based on French legal thinking, the Lao code follows the Romance system of maternal and paternal acknowlegement as a prerequisite in conferring the status of filiation and 